\title{
Strategy of Facility Development in The Tourist Attraction of Ujuang Batu Padang Beach
}

\author{
Lise Asnur ${ }^{1}$, Andri Arja Manggara ${ }^{2}$ \\ \{lise.asnur@fpp.unp.ac.id\} \\ Tourism Department, Universitas Negeri Padang, Indonesia ${ }^{12}$
}

\begin{abstract}
This research aims to determine the strategy of facility development in the tourist attraction of Ujuang Batu Padang beach using SWOT analysis. This research is a descriptive study with qualitative data, the type of data used is primary data and secondary data. Data collection techniques are carried out using interview, observation and documentation methods. The informants in this study were determined by using purposive sampling, as well as informants who became speakers in this study namely the management and chairman (RT), the people around tourist attractions and tourists in the tourist attraction of Ujuang Batu Beach. Then this research uses interactive model data analysis techniques namely data reduction, data presentation, and conclusion retrieval. Based on the results of this research the strategy of developing a beach tourism attraction facility ujuang batu Is 1) Cooperation with every business person in the tourist attraction in improving cleanliness. 2) Optimize available parking spaces. 3) Make an offer to everyone in opening a food and beverage business in the tourist attraction. 4) Utilizing land that is still large in equipping facilities that are not yet available. 5) Cooperate with the government, private parties and local communities in improving and equipping facilities in tourist attractions.
\end{abstract}

Keywords: Strategy; Development; Tourist Facilities

\section{Introduction}

Tourism sector is one of the sectors that provides a lot of foreign exchange income for the country. Tourism has a function for tourists to meet physical and spiritual needs as well as intellectual needs by traveling. The benefits of tourism can increase the country's income for the welfare of the people and hope in spurring and promoting economic growth in the community. Where the management of tourist attractions is good in an area: natural tourism, cultural tourism, religious tourism, culinary tourism and other tourism will increase revenue and increase sustainable development in the area. Padang is the Capital of West Sumatra Province and is the largest city on the island of Sumatra. When mentioning the word Padang definitely that is in our minds is the typical food that is rendang. In addition to rendang we also know Padang from Padang restaurants scattered throughout the country, not only its delicious culinary taste Padang is also famous as an interesting tourist destination.

Most of Padang's population consists of Minangkabau ethnicities, they have a unique culture and must be traced such as traditional houses, heritage history and other unique places that can be visited to get to know more in Minang culture. In addition to Minang culture, Padang is also famous for beautiful beach tourism and pampering eyes. Padang's beaches have 
their own uniqueness (quoted from https://www.itrip.id/wisata-pantai-padang accessed 26 October 2020).

One of the beach tourism attractions in Padang City is Ujuang Batu Beach. Ujuang Batu Beach is located in Pasia Sabalah Pasia Nan tigo Village, Koto Tangah District, Padang, West Sumatra. The beach which is about 5 Kilometers from Padang State University (UNP) can be reached using angkot majoring tabing or Lubuk Buaya to simpang Muaro Penjalinan and continue walking or you can use the ojek service approximately 500 meters away, Ujuang Batu Beach has a natural view that is still beautiful and far from the noise, so it is suitable as a relaxing place with friends, couples and families in the afternoon with shady pine trees lined neatly and rocks arranged into breakwater. In addition, this tourist attraction also offers a beach with good waves for surfing for local tourists and surfers to practice and learn to surf and the tourist attraction of Ujuang Batu Beach has also been the place to hold the 'Surfing Competition Walikota Cup 2019. Simply pay in five-thousand-rupiah visitors can already enjoy the beauty of this tourist attraction.

Tourist facilities are an important element in providing services to tourists while in a tourist attraction and have an influence on developments in tourist attractions. Facilities are facilities and infrastructure that support the operation of tourist attractions to accommodate all the needs of tourists, not directly encouraging growth but developing at the same time or after the attraction develops. According to Spillane theory, facilities can be grouped into three: 1) The main facilities, are much needed and felt very necessary as long as visitors are in a tourist attraction. 2) Supporting facilities, facilities that are in proportion to the main facilities so that tourists will feel more at home. 3) Supporting facilities, is a facility that is the main complement so that tourists are met whatever the needs during visiting (Spillane in wahyuningsih 2018: 4).

Based on the pre-observation conducted, the authors found some problems related to facilities in the tourist attraction ujung batu beach (1) There is no place to eat in the tourist attraction of Ujuang Batu Beach, such as: restaurants or cafes. (2) There is no accommodation available in the tourist attraction of Ujuang Batu Beach. (3) There is no souvenir and souvenir shop available at Ujuang Batu Beach tourist attraction. (4) Road access to Ujuang Batu Beach tourist attraction is already on the asphalt but there are still holes. (5) Seating in the form of benches provided for tourists in the tourist attraction of Ujuang Batu Beach does not yet exist.

(6) Parking vehicles that are not well organized in the tourist attraction of Ujuang Batu Beach.

(7) Garbage scattered on the beach and the provision of trash cans in the tourist attraction of Ujuang Batu Beach which is still minimal.

Based on the findings the authors are interested in conducting further research on the facilities in the tourist attraction of Ujuang Batu Beach. With the title "Ujuang Batu Padang Beach Tourism Attraction Facility Development Strategy". With the conduct of this research is expected to determine the right strategy in the development of facilities in the tourist attraction of Ujuang Batu Beach. So, with the increasing facilities in ujuang batu beach attraction, it will be more interesting for tourists to come. If there is no improvement in the facilities in this attraction, it is feared that there will be a decrease in tourist interest.

\section{Methodology}

This research is classified as a descriptive study with qualitative data, instruments in the study namely the researchers themselves. This research was conducted in the tourist attraction 
of Ujung Batu Pasia Sabalah Beach, Pasia Nan Tigo village, Koto Tangah District, Padang, West Sumatra. The data sources used are primary and secondary data (Purhantara, 2010: 79). The data collection techniques used in the study are Observation, Interview and Documentation (Sugiyono 2013: 224). For data obtained from several informants using purposive sampling techniques, the informant who became the source in the research was the manager and chairman of RT tourism area, 2 people of the surrounding community and 4 tourists. This research uses interactive model data analysis techniques namely data reduction, data presentation, and conclusion retrieval (Miles and Huberman in Sugiyono 2013: 246).

\section{Result and Discussion}

\subsection{Main Facilities}

a. Cleanliness

Based on the results of interviews with some informants can be concluded that the cleanliness in the tourist attraction of ujuang batu beach is still lacking, where the front of the attraction is clean but the part of the beach is still a lot of garbage scattered. This is due to several factors, namely the lack of awareness of visitors maintaining cleanliness and the location of this attraction next to the estuary (the meeting of river water with the sea) so that the garbage in the river is carried into the sea and waves send it to the beach. In the future, it is expected that the cleanliness of the beach is more noticed so that tourists feel happy / satisfied to be in the tourist attraction of ujuang batu beach.

\section{b. Beauty}

Based on the results of interviews with several informants can be concluded that the beauty in the tourist attraction of ujuang batu beach has a beautiful view but that disturbing the beauty in this place is the problem of garbage and the absence of shipwrecks on the shore. In the future in this attraction will be more laid out and expected not diminished beauty in this tourist attraction because of the development carried out in the future. For today's barriers the manager is still moving on his own, there has been no support and lack of community initiative.

c. Comfort

Based on the results of interviews with several informants it can be concluded that for convenience in this place is already comfortable with the absence of confectioners and no illegal levies but what interferes with the current comfort is the problem of garbage.

\subsection{Complementary facilities}

a. Public toilets

Based on the results of interviews with several informants it can be concluded that toilets in the tourist attraction of ujuang batu beach already exist but the current condition is being damaged and the location of the toilet construction is not appropriate so tourists are not easy to find it. For the foreseeable future the toilet will be improved again according to tourism standards but for now the funds are not yet available for it.

b. Road

Based on the results of interviews with several informants it can be concluded that the condition of the road can already be in the access where the road has been paved but there is 
still a hole in the road. For the foreseeable future the condition of the road is more considered so that tourists are comfortable to drive.

\section{c. Places of worship}

Based on the results of interviews with several informants can be concluded that places of worship already exist near this attraction which belongs to the local community and can be used by tourists, for the condition of good places of worship, there are already available places of wudoo', mukena, sarong and prayer mats. Behind that the manager also issued money contributions to the mushalla and for the future will be kept clean.

\section{d. Seating}

Based on the results of interviews with several informants can be concluded that seating in the attraction for now has not been provided, in the future will be made seating and tables of wood and will be built gazebo in the beach section and under the fir trees where there is already a design. for those who impede that the funds are not yet available and are feared to be misuse by tourists for bad deeds.

\section{e. Trash cans}

Based on the results of interviews with several informants can be concluded that for now there is not a trash can in this attraction, previously there have been ten trash cans of drums that were halved but now only one stay and the condition is not feasible because this drum of iron is finally torn and destroyed eaten time, so for visitors who brackets will clean up litter, in the future, garbage cans are provided so that visitors do not throw away the garbage.

\section{f. Parking lot}

Based on the results of interviews with several informants can be concluded parking lot in the beach attraction ujuang rock land is spacious but the condition of the parking layout is still scattered, previously the manager has applied to visitors parking lot but due to the limitations of other facilities that do not exist such as seating so that tourists park where they are comfortable sitting and for now need to understand it. For the foreseeable future parking is more noticed and the need for parking attendants for security and arranging parking.

\subsection{Supporting Facilities}

a. Accommodation

Based on the results of interviews with some informants it can be concluded that for suitable lodging in this place such as Homestay because it is necessary for tourists from outside the area, for family tours or people who are far away and not likely to go home but there must be clear rules so as not to occur abuse that results in the image in this place decreases. Where at this time there are already houses of residents who are willing to be used as a homestay, with so will be safer and easier to monitor.

b. Place to eat and drink

Based on the results of interviews with several informants can be concluded that the place to eat and drink in the tourist attraction of ujuang batu beach is now a place to eat and drink in the form of a café in the form of a café in the development that will be completed and in the future there are already four more that are expected to be completed by the end of December, for the menu in each place of eating and drinking should not be the same and as a typical food here namely pukek side dishes. In the future make rules in every place to eat and drink so that there is no abuse in this tourist attraction and also in the future there is certainly competition with places to eat and drink around tourist attractions. 


\section{c. Place of sale of by-sales}

Based on the results of interviews with several informants it can be concluded that For the sale of by-products has not existed in the tourist attraction of ujuang batu beach and its surroundings, It should be a tourist attraction every beach there sells by-products so that tourists have a bey from the place they visit. In the future, there will be souvenirs in every café that will be built in the form of miniature souvenir boats as typical souvenirs on this beach and also sell beach clothes, for the obstacles of souvenir providers in tourist attractions currently have no funds.

There are two factors in determining the strategy: a) Internal factors: the strengths and weaknesses of the tourist attraction facilities. b) External factors: opportunities and threats from tourist attraction facilities (Maryam 2011: 44).

\subsection{Analysis of Ujuang Batu Beach Attraction Facility}

a. The strength of the facilities in the tourist attraction of Ujuang Batu Beach include: (1) The front of the attraction is clean. (2) Beautiful natural scenery. (3) The place is safe and comfortable, nothing. or ignition. (4) Location of the attraction. Strategic location, it is not far from the main road and is at the meeting of the river with the sea (estuary). (5) There are already street vendors selling at tourist attractions. (6) Public toilets are available. (7) The road to the attraction is already on the asphalt. (8) There is already a seating design to be made at the attraction. (9) Spacious parking lot. (10) Place to eat and drink in the development process. (11) There is still a large area of land for development.

b. The weakness of the facilities in the tourist attraction of Ujuang Batu Beach include: (1) The beach section is still dirty, garbage is strewn along the beach. (2) A shipwreck on the shore which disturbs the view. (3) The toilet is currently in a damaged condition. (4) The location of the toilet is not precise so it makes it difficult for visitors to find the toilet. (5) Bench seating is not yet available. (6) Parking conditions have not been neatly arranged. (7) Trash cans are not yet available. (8) There are no places of worship in the tourist area. (9) The condition of the road to the tourist attraction still has holes. (10) There is no place to sell souvenirs. (11) No accommodation or accommodation yet. (12) Limited funds needed to develop.

c. Facilities opportunities in the tourist attraction of Ujuang Batu Beach include: (1)

Working with related parties. (2) The community's musholla is near the attraction. (3) Increase visitor satisfaction. (4) Create jobs. (5) Increase revenue. (6) Public housing is ready to be used as a homestay.

d. The threat of facilities in the tourist attraction of Ujuang Batu Beach include: (1) Natural factors in the form of garbage from the estuary carried into the sea and pushed waves to the beach. (2) Lack of awareness of visitors in maintaining cleanliness. (3) Low community participation to play a role in the development of tourist attractions. (4) The iron bins are finally torn down and destroyed and the garbage is strewn by dogs. (5) competition with places to eat and drink around the attraction. (6) Misuse of tourist facilities. (7) No investors yet.

\section{b. The Strategy for the Development of the Ujuang Batu Beach Tourist Attraction Facility}

a. Strategi SO

- Cooperate by applying regulations to every business person in the attraction to clean their surrounding area every day before leaving the place. 
- Optimize the available parking space by creating a boundary in the parking lot area and making a special place for cars and motorcycles by preferable a special place for cars from the main road to the parking lot so that it is easier to get in and out and improve the smooth parking.

- Promoting directly or through social media to everyone, especially the local community, that at this time hold an offer in the form of leasing a place of business for those who want to open a food and beverage business in this attraction.

- Utilizing land to build facilities that are not yet available with regard to the selection of locations and the impact of future development.

b. WO Strategy

- Submit proposals to the cleaning service as well as the environment office in improving cleanliness and the provider of necessary tools in cleanliness in tourist attractions.

- Submit a proposal to the public workers office (pu) in making road repairs to the attraction to improve the comfort of visitors in driving.

- Submit proposals to private parties (companies) to obtain csr (corporate social responsibility) funds in holding facilities in tourist attractions.

- Cooperate with the surrounding community to move the shipwrecks that are on the shore to a more appropriate place.

- Repair and repair the toilet and make the toilet signboard.

- Utilizing the local community's musholla that is already near the tourist attraction for visitors can perform prayer services and supervise in maintaining the cleanliness of the mosque and spending money contributions from special tourist attractions for the mushola, then also this should be deliberation with the local community so that there are no misunderstandings in the future.

- Cooperate with the community, especially the surrounding youth to form a parking attendant who can direct, organize and maintain parking security at the attraction.

- Providing accommodation (lodging) by utilizing the surrounding community house to be used as a homestay by taking care of its operational license in the form of a list of tourism businesses (tdup) addressed to the head of the investment office and integrated one-door service (DPMPTSP) Padang city.

c. ST Strategy

- Applying to every food or beverage business owner in the tourist area should have different main menus with regard to taste, determine the right price and utilize social media in promoting the business. Then in this tourist area must also provide one place of food and drink that sells typical food here that is the menu of pukek side dishes.

- Conducting daily supervision to avoid misconduct or misuse in tourist areas by visitors, as well as making policies for misuse in tourist attractions by imposing sanctions in accordance with the nagari regulations for the behavior of deviant visitors.

- Conduct promotional activities through social media using words that attract attention and use images that have a mix of colors both in increasing the number of visits and also to attract investors. 


\section{d. WT Strategy}

- Hold a plastic bin grouped into organic and non-organic waste. It then creates a warning board that calls on visitors to throw rubbish into place and imposes sanctions for visitors who do not comply with the rules on cleanliness at the attraction.

- Provide a trash can in the toilet so that the user does not throw his garbage into the toilet hole, make a warning sign in the toilet to keep the toilet clean and check the trash can in the toilet every day and empty the trash can in the toilet if it is full so that there is no buildup of garbage in the toilet.

- Maximize the function of the manager to the surrounding community by providing periodic briefing, training and coaching to the community about the importance of tourist attractions in the community environment.

\section{Conclusion}

The conclusion of the research on the strategy of developing the tourist attraction facilities of Ujuang Batu Beach is to determine the internal factors of the facility including the strength and weakness of the tourist attraction facilities of Ujuang Batu Beach as well as determining external factors of facilities that include opportunities and threats in developing the tourist attraction facilities of Ujuang Batu Beach. Then formulate the right strategy for the development of ujuang batu beach tourist attraction facilities.

\section{References}

[1] Sugiyono. (2013). Metode Penelitian Kuantitatif, Kualitatif dan R\&D. Bandung: Alfabeta.

[2] Wahyuningsih, ririn. (2018). Persepsi pengunjung terhadap fasilitas di objek wisata puncak ulu kasok kabupaten Kampar. Jurnal JOM FISIP, 5(2), 1-13.

[3] Purhantara, Wahyu. (2010). Metode Penelitian Kualitatif untuk Bisnis. Yogyakarta: Graha Ilmu.

[4] https://www.itrip.id/wisata-pantai-padang. diakses 26 oktober 2020. 